JOURNAL OF SECURITY AND SUSTAINABILITY ISSUES

ISSN 2029-7017 print/ISSN 2029-7025 online

2019 December Volume 9 Number 2

http://doi.org/10.9770/jssi.2019.9.2(4)

Scopus

\title{
TOWARDS SUSTAINABLE DEVELOPMENT: THE ROLE OF R\&D SPILLOVERS IN INNOVATION DEVELOPMENT
}

\author{
Zenona Ona Atkočiūnienė $\dot{1}^{1}$ Olga Miroshnychenko \\ ${ }^{1}$ Vilnius University, 3 Universiteto St., LT-01513 Vilnius, Lithuania \\ ${ }^{2}$ Taras Shevchenko National University of Kyiv, 60 Volodymyrska St., Kyiv, 01033 Ukraine \\ E-mails: ${ }^{1} z e n o n a . a t k o c i u n i e n e @ k f . v u . l t ;{ }^{2}$ olgamir.ua@gmail.com
}

Received 22 March 2019; accepted 18 November 2019; published 30 December 2019

\begin{abstract}
One of the most essential strategic resources of the company is the knowledge that is used and developed within the company, creating innovations, and can be transferred among other companies, organizations, industrial sectors, and countries. The key reason for this spill over is the vulnerability of knowledge transfer channels. Knowledge is quickly transmitted through the media, scientific publications, reverse engineering, $R \& D$ cooperation, interaction between staff of various firms, companies, and organizations. In addition, knowledge cannot fully belong to the organization. R\&D spillovers have a positive impact on innovation development; promote access to knowledge and its dissemination on a non-profit basis which enhances R\&D cooperation between different economic entities, organizations, countries in the field of innovation diffusion. The contribution of R\&D spillovers to achieving innovation development, the relationship between knowledge spillovers, innovation and R\&D cooperation have been thoroughly examined. Differences between knowledge spillovers, knowledge transfers, and knowledge externalities have been identified. Types of R\&D spillovers and levels of knowledge spillovers have been considered. Mechanism and theories of knowledge spillovers and local competition have been analysed. Comparative, systematic and critical analysis of scientific literature has been used in order to create the theoretical background for research of R\&D spillovers and their impact on innovation development and economic growth.
\end{abstract}

Keywords: innovation; spillovers; R\&D spillovers; types of R\&D spillovers; knowledge spillovers

Reference to this paper should be made as follows: Atkočiūnienė, Z.O., Miroshnychenko, O. 2019. Towards sustainable development: the role of r\&d spillovers in innovation development, Journal of Security and Sustainability Issues 9(2): 409-419.

http://doi.org/10.9770/jssi.2019.9.2(4)

JEL Classifications: O31, R11

\section{Introduction}

Sustainable development is dependent on innovation performance. Knowledge and innovation have a vital role in ensuring the competitiveness of the company. The development of the knowledge economy shifts the focus to the use of technological innovations to create and disseminate new knowledge through the development of innovative products and processes. The creation of innovation does not occur in isolation, in particular due to complexity, high risks and costs, and therefore the importance of R\&D is increasing (Montoro-Sa'nchez, A. et al., 2011, Petrenko, Y. et al., 2019, Girdzijauskaite, E. et al., 2019; Šimonová, J. et al., 2019; Hrivnak, M. et al., 2019; Bezpalov, V.V. et al, 2019).

One of the most essential strategic resources of the company is the knowledge that is used and developed within the company, creating innovations, and can be distributed among other companies. The vulnerability of knowledge exchange channels lies at the bottom of this distribution. Knowledge can be quickly transferred through the media, scientific publications, reverse engineering, scientific cooperation, interaction between staff 
members of various companies and organizations, patent disclosures, scientific exchange programs and scientific collaboration, etc. In addition, knowledge cannot belong entirely to the company, organization or individual producing them due to its imperfect appropriability (Griliches, Z., 1979; Cohen, W., Levinthal, D., 1989; Krchová, H., 2019; Lysytsia, N. et al., 2019; Batkovskiy, A.M. et al., 2019; Hasan, M., 2019).

Knowledge obtained by the company in the course of R\&D may "spill over" to another company and bring it an economic benefit resulting from their use, R\&D spillover effects (Jaffe, A.B., 1986). Spillovers occur if an innovation implemented by one entity increases the performance of another entity without the latter benefiting entity having to pay (full) compensation (Van Stel, A.J., Nieuwenhuijsen, H.R., 2004, p. 4). Companies can often acquire external knowledge, which was transferred through different channels, without having to pay for it (Verspagen, 1997). Rehme, J., Staffan, S. (2017, p. 9) define spillovers as "thus "externalities" to large hightech development projects, i.e. that is not included in the original contract". Levin, R.C., Reiss, P.C. (1988) and De Bondt, R. (1996) describe spillover as the side effects of company’s R\&D investment strategies.

The R\&D spillover has its origin in 1890, where Alfred Marshall noted that "the secrecy of business is on the whole diminishing, and the most important improvements in method seldom remain secret for long after they have passed from the experimental stage" (Marshall, A., 1920). Alfred Marshall's theory was later extended by Kenneth Arrow (Arrow, K., 1962) and Paul Romer (Romer, P., 1986) and abbreviated as MAR (Marshall- Arrow- Romer).

The objective of this research paper is to determine the key characteristics of R\&D spillovers and create the theoretical background for measuring the impact of R\&D spillover on innovation development. The structure of the paper is arranged as follows: the review of relevant literature associated with the research topic is summarized in Section 2, the methodology is elaborated in Section 3, and the results of the research are provided in Section 4. Discussion and conclusions are presented at the end of the paper.

\section{Literature Review}

The importance of R\&D spillover aimed at enhancing innovation development is widely recognized in the modern endogenous growth theories (Romer, P.M., 1986, 1994; Lucas, R.E., 1988), international trade (Grossman, G., Helpman, E., 1990, 1991, 2015; Branstetter, L., Saggi, K., 2011); international investment (Keller, W., 1998, 2004). The early empirical works on R\&D spillover were done by Arrow, K., (1962), Jacobs, J. (1969), Romer, P., 1986, Jaffe, A.B. (1986), Griliches, Z. (1979), Levin, R.C. and Reiss, P.C. (1988), Cohen, W. and Levinthal, D. (1989).

The topic of international R\&D spillovers were covered in research papers by Grossman, G. and Helpman, E. (1990, 1991, 2015), Keller W. (1998, 2004), Branstetter, L. and Saggi, K. (2011), Feriyanto, N., Muafi, Dityawarman, E. A. (2019). The impact of R\&D spillovers have been evidenced by data from a number of countries worldwide including Canada and USA (Bernstein, J. 2000), Australia (Bakhtiari S., Robert B., 2016), Europe (Bayar, A., Dramais F. et al., 2007), the Balkans countries (Ramadani, V. et al., 2017), Dutch regions (Van Stel A.J., Nieuwenhuijsen H.R., 2004), Finland (Simonen, J., McCann, P., 2008), Sweden and Brazil (Rehme, J., Staffan, S., 2017), Japan (Kenta et al., 2015), Korea (Lee, K., Chen, K., Yoon, M., 2016) etc.

The role of R\&D spillovers in strategic entrepreneurship have been examined in research conducted by Van Stel A. (2006), Agarwal, R., Audretsch, D., and Sarkar, M. (2010), Ferreira, J.J., Ratten, V., and Dana, L.-P. (2017). The process of knowledge spillovers were analysed to find the evidence for small firms (Audretsch, D.B., 1999), and social enterprises (Ko, W. W., \& Liu, G., 2015). Intersectoral technology spillovers were estimated by Verspagen, B. and De Loo, I. (1999), using the European and U.S. Patent Office databases - Verspagen, B. (1997). Connection between R\&D spillovers and innovation development was a subject of a wide range of studies conducted by De Bondt, R. (1996), Audretsch, D.B. (1998), Breschi, S. and Lissoni, F. (2000), Fallah, M.H. and Sherwat, I. (2004), Montoro-Sa'nchez, A., Ortiz-de-Urbina-Criado, M., Mora-Valent1'n, E. (2011), Medhurst, J., Marsden J., Jugnauth F., Peacock, M., and Lonsdale, J. (2014), Miroshnychenko, O. (2019). 


\section{Methods}

In the following paper, systematic and comparative analyses of academic literature have been used to examine the concept of R\&D spillovers and innovation, definitions of knowledge spillovers, the evolution of knowledge spillovers theories, and the research covering the relationship between elements of knowledge spillovers mechanism. Comparative, systematic and critical analyses have been applied to identify and classify the types of R\&D spillovers (knowledge, market, and network spillovers) and types of knowledge spillovers. The inductive method has been employed to substantiate the levels of knowledge spillovers i.e. individual, enterprise and global levels. By using the deductive method, the difference between knowledge transfers, knowledge spillovers and knowledge externalities was identified, and an integrated model was formed based thereon. Synthesis and interpretation were used to draw conclusions of the paper.

\section{Results}

\section{Definitions of Knowledge Spillovers}

Knowledge spillovers promote access to knowledge and its dissemination on a non-profit basis, while enhancing cooperation between different business entities, organizations, industrial sectors, and countries in the field of innovation diffusion. Knowledge spillovers have a positive effect on innovation development (Verspagen, B., De Loo, I., 1999). E.g. while company A creates innovation, other companies may use the knowledge developed by company A as a part of the said innovation in their own activities. Aside from the aforementioned, knowledge spillovers enhance inter-organizational collaboration in spreading and gaining access to knowledge, and thus have a positive impact on cooperation agreements (Simonen, J., McCann, P., 2008). Knowledge spillovers occur due to failures in the legal protection mechanisms (patents, copyright, trademarks, trade secrets, etc.) of knowledge generating companies (Fallah, M.H., Sherwat, I., 2004). The key definitions of knowledge spillovers are given in the table below (see Table 1).

Table 1. Definitions of Knowledge Spillovers

\begin{tabular}{|c|c|}
\hline Authors & Definitions \\
\hline $\begin{array}{l}\text { Griliches, Z. (1979); } \\
\text { Bayar, A. et al. (2007), } \\
\text { p. } 14\end{array}$ & $\begin{array}{l}\text { "Knowledge spillovers that arise because of the imperfect appropriability of knowledge: poor patent protec- } \\
\text { tion, reverse engineering,... are pervasive phenomena that contribute to the diffusion of knowledge." }\end{array}$ \\
\hline $\begin{array}{l}\text { Grossman, G., } \\
\text { Helpman, E. (1991), } \\
\text { p. } 16\end{array}$ & $\begin{array}{l}\text { "The partial nonexcludability of knowledge suggests that industrial R\&D may generate "technological spill- } \\
\text { overs". By technological spillovers we mean that (1) firms can acquire information created by others without } \\
\text { paying for that information in market transaction, and (2) the creators or (current owners) have no effective } \\
\text { recourse, under prevailing laws, if other firms utilize information so acquired." }\end{array}$ \\
\hline $\begin{array}{l}\text { Jaffe, A.B., } 1998, \\
\text { p. } 11\end{array}$ & $\begin{array}{l}\text { "Knowledge created by one agent can be used by another without compensation, or with compensation less } \\
\text { than the value of the knowledge. Knowledge spillovers are particularly likely to result from basic research, } \\
\text { but they are also produced by applied research and technology development." }\end{array}$ \\
\hline $\begin{array}{l}\text { Breschi, S., Lissoni, F. } \\
\quad(2000), \text { p. } 1\end{array}$ & $\begin{array}{l}\text { "Localized knowledge spillovers" (LKS), can be defined as "knowledge externalities bounded in space", } \\
\text { which allow companies operating nearby the knowledge sources to introduce innovations at a faster rate than } \\
\text { rival firms located elsewhere." }\end{array}$ \\
\hline $\begin{array}{l}\text { Fallah, M.H., } \\
\text { Sherwat, I. (2004), p. } 8\end{array}$ & "Spillovers are the unintentional transmission of knowledge to others beyond the intended boundary." \\
\hline $\begin{array}{l}\text { Keller, W. (2004), } \\
\quad \text { p. } 753\end{array}$ & $\begin{array}{l}\text { "The partially private, partially public nature of the return to technological investments implies that while } \\
\text { there is a force that might be strong enough to sustain the private incentive to innovate (the private return, } \\
\text { which is often a temporary monopoly), technological investments may also create benefits to firms and in- } \\
\text { dividuals external to the inventor by adding to their knowledge base (the public return). These benefits are } \\
\text { usually called knowledge spillovers. An example is that the design of a new product might speed up the } \\
\text { invention of a competing product, because the second inventor can learn from the first by carefully studying } \\
\text { the product, or even the production design". }\end{array}$ \\
\hline $\begin{array}{l}\text { Kafouros, M.I., } \\
\text { Buckley, P.J. (2008) }\end{array}$ & Knowledge spillovers occur when a firm exploits knowledge and ideas developed by other firms. \\
\hline
\end{tabular}




\begin{tabular}{|c|l|}
\hline $\begin{array}{c}\text { Yang, H., } \\
\text { Steensma, H.K., } \\
\text { (2014), p. } 1496\end{array}$ & $\begin{array}{l}\text { "Knowledge spillover occurs when recipient firms combine the knowledge of an originating firm with other } \\
\text { knowledge. When recipient firms combine the originating firm's knowledge with knowledge that is unfamil- } \\
\text { iar to the originating firm, the recipient firms potentially provide insight to the originating firm on the viabil- } \\
\text { ity of exploring such knowledge." }\end{array}$ \\
\hline $\begin{array}{c}\text { Agarwal, R. } \\
\text { et al. (2010), p. } 271\end{array}$ & $\begin{array}{l}\text { Knowledge spillovers, can be defined also as the external benefits from "the creation of knowledge that ac- } \\
\text { crue to parties other than the creator, occur at multiple levels of analysis, be it within or across organizations } \\
\text { and networks." }\end{array}$ \\
\hline $\begin{array}{c}\text { Ko, W.W., Liu, G. } \\
(2015), \text { p. } 66\end{array}$ & Knowledge spillovers are "unintentional flows of knowledge from one network party to another." \\
\hline $\begin{array}{c}\text { Ramadani, V. et al. } \\
\text { (2017), p. } 301\end{array}$ & "The process of gaining new knowledge from other firms beside ours is called knowledge spillover." \\
\hline $\begin{array}{c}\text { Ferreira, J.J. et al. } \\
\text { (2017), p. } 162\end{array}$ & $\begin{array}{l}\text { "Knowledge spillover-based strategic entrepreneurship as unintentional knowledge flows that can be used for } \\
\text { strategic purposes to network entities other than the creators for innovative, risk taking, proactive and com- } \\
\text { petitive business reasons." }\end{array}$ \\
\hline
\end{tabular}

Source: compiled by the authors

There is a connection between knowledge externalities, knowledge transfers, and knowledge spillovers (see Figure 1). The term "externality" was introduced by Alfred Marshall (Marshall, A., 1890) and developed by Arthur C. Pigou (Pigou, A. C., 1920) in his book "The Economics of Welfare" in 1920 (Tsyplakova, D., 2010). The externality can be defined as costs incurred or benefits received by a third party which is not directly involved in the creation of the said cost or benefit. R\&D is an example of positive externalities. Knowledge transfers and knowledge spillovers are the sources of externalities; and externalities are indicative of a positive effect of knowledge transfers and knowledge spillovers on innovation development. If the knowledge is transmitted intentionally, it is known as knowledge transfer (publications, presentations, formal training etc.). Due to the knowledge exchange, knowledge transfer involves cross-party collaboration and compensation. The external benefits of the knowledge creation through knowledge spillovers are accrued to the network parties other than the innovator (Ko, W.W., Liu, G., 2015). "Knowledge spillovers are the unintentional transmission of knowledge to others beyond the intended boundary" (Fallah, M.H., Sherwat, I., 2004, p. 8). There are various knowledge exchange channels, through which information can be transferred from one agent to another (see Figure 1).

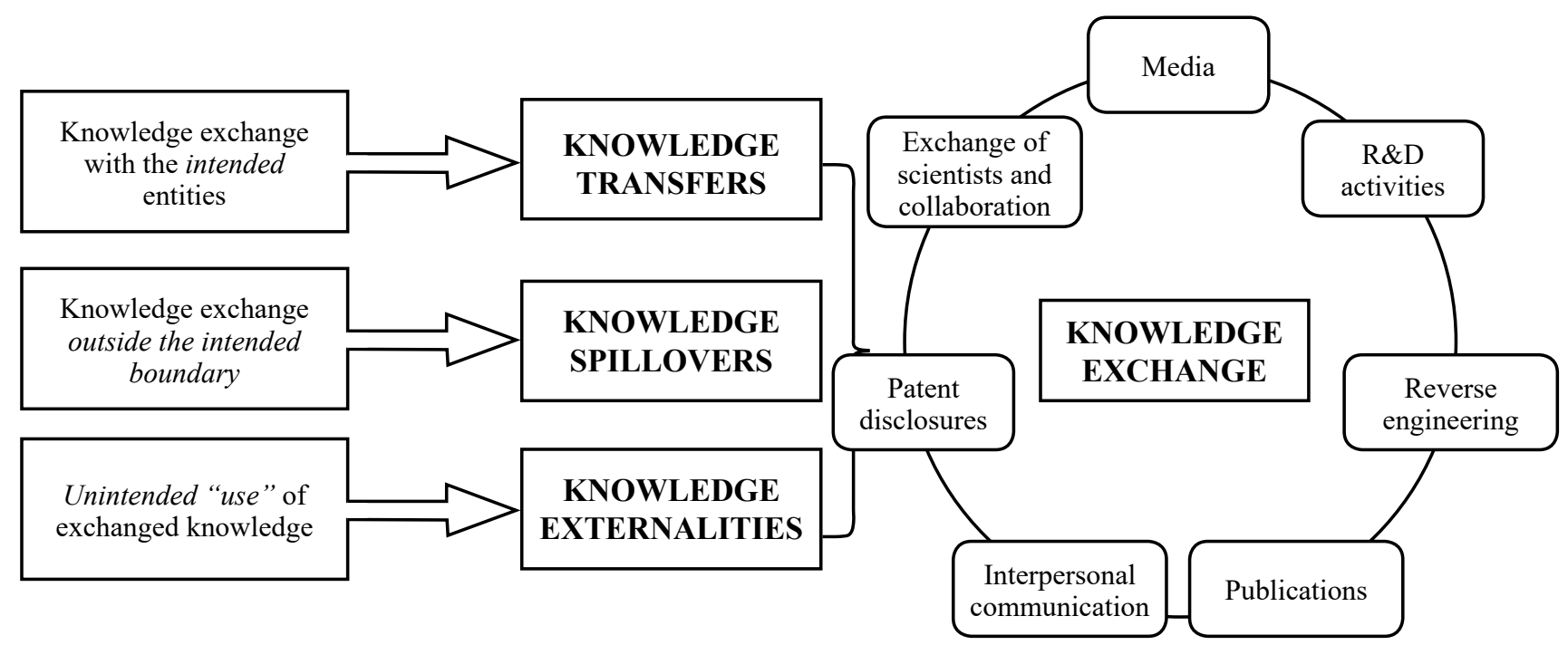

Fig. 1. The Difference between Knowledge Transfers, Knowledge Spillovers and Knowledge Externalities

Source: compiled by paper authors based on research results 
Due to the knowledge flows, knowledge is created, captured, retained, and applied. Every possible interaction creates potential for knowledge spillovers and spillover flows, can enhance innovation activity and result in innovation diffusion. Spillover flows consist of tacit and explicit knowledge that arises within the entities (companies, firms, and institutions) and through market transactions or knowledge exchanges between people, companies, institutions, industries, and even across nations. Hence, sharing knowledge outside the intended entity (agent, economic unit) and unintended use of knowledge can result in different types of spillovers and cause knowledge externalities.

\section{Types of R\&D Spillovers}

Three distinct types of R\&D spillovers have been identified in the academic literature. These are namely knowledge spillovers, market spillovers, and network spillovers (Jaffe, A.B., 1998; Jones, C.I., Williams C.W., 1998; Medhurst, J. et al., 2014):

1. Knowledge spillovers mean the use of knowledge from the agents without full compensation in order to generate economic, social or environmental benefits. Creation, transfer, absorption of knowledge, and its commercialisation lead to dissemination of knowledge and increase in the scale of spillovers (e.g. through knowledge sharing, employee mobility, the use of published scientific papers etc.).

2. Market spillovers occur if market participants receive some of the benefits that arose through the operation of the market for a new product other than the innovating companies. The key difference between market spillovers and knowledge spillovers is this "leakage" of benefits through the activities of market forces, rather than the flow of knowledge itself. Whenever a company creates a new product, improves the existing one or reduces the existing product's manufacturing cost, the natural operation of market forces will tend to cause some of the benefits thereby created to be "spilled over" to consumers. As a result, buyers will be made better off by the introduction of the new or improved product. Implementation of innovation often results in both higher quality and lower prices, and thereby customers have social benefit that is not captured by the innovator (Jaffe, A.B., 1998).

3. Network spillovers occur when the value of a new technology is highly dependent on the development of a set of related technologies. Adam B. Jaffe (1998, p. 12) notes that "the different related research projects are like the different users of a network", thereby the term "network spillover" has been chosen. "The value of a network to any one participant is an increasing function of the number of participants; here the expected value of any one research project is an increasing function of the number of different projects undertaken" (Jaffe, A.B., 1998, p. 12). The examples of network spillovers have been considered by James Medhurst, Joel Marsden, Angina Jugnauth, Mark Peacock, Jonathan Lonsdale (Medhurst, J. et al., 2014) as a result of the technology support programme. They defined network spillovers as "the effect of programme innovation on the development of a "critical mass" of users, where the take-up of the innovation by additional users, increases the value of the innovation to existing users (for example, computer games)" (Medhurst, J. et al., 2014, p. 8). Network spillovers exist even if there are no knowledge spillovers among the companies, although knowledge spillovers are also likely to arise (Jaffe, A.B., 1998).

\section{Levels and Types of Knowledge Spillovers}

Tacit and explicit knowledge can be exchanged at different levels, in different forms, and the reason for such exchange may vary as well. Knowledge flows take place among individuals or through knowledge transmission via the human capital acquisition, across companies, or between companies and organizations, as well as between countries (see Figure 2). 


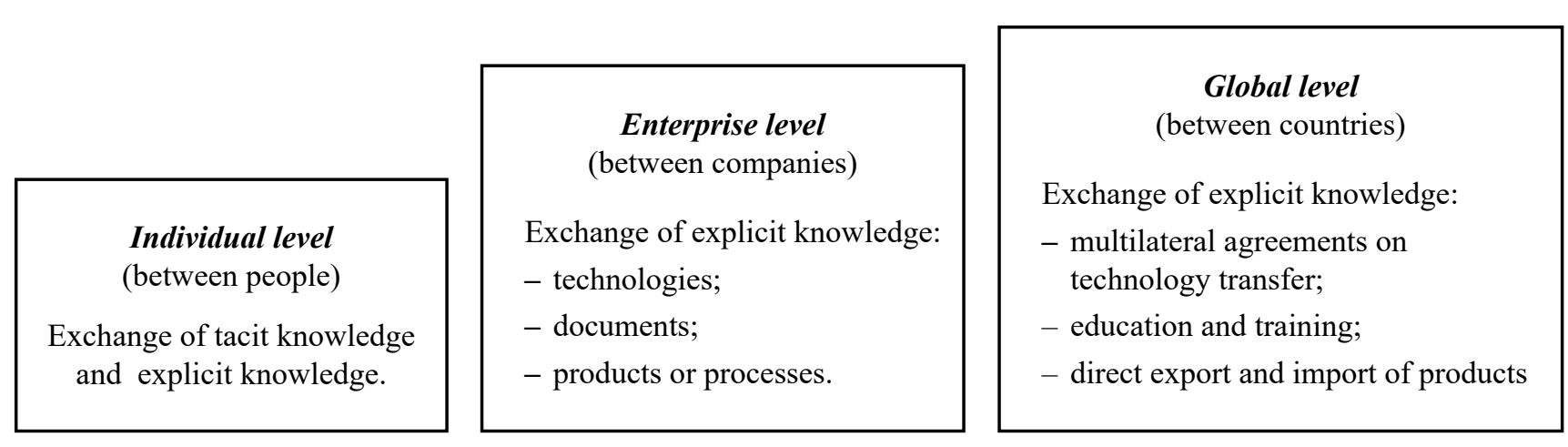

Fig. 2. Levels of Knowledge Spillovers

Source: compiled by paper authors based on research results

Most literature sources emphasize three levels of knowledge spillovers:

1. Individual level (among people). Knowledge can be unintentionally exchanged between members of a team working together, whether from within the same companies, organizations or from different entities. Faceto-face interactions and social contacts are important for knowledge diffusion (Van Stel, A.J., Nieuwenhuijsen, H.R., 2004). Knowledge spillovers can arise through information shared outside the group of people, outside company or organization (knowledge exchange across customers, inventors, scientists, and researchers who are not intended to possess such knowledge).

2. Enterprise level (among companies, and firms). Any unintended exchange of information between companies is known as knowledge spillover. For instance, it can arise when the private companies are getting involved in B2B relationships. Knowledge spillovers can happen:

- between companies located in close proximity (between neighboring companies) as a result of industry specialization (Marshall, A., 1890; Arrow, K., 1962; Romer, P., 1986), if companies operate in industries that are geographically concentrated (Jaffe, A.B.,1986).

- if companies are doing business together as a result of the diversity and variety of knowledge between complementary industries or customers and suppliers that service each other (Fallah, M.H., Sherwat, I., 2004); a knowledge spillover effect is observed when one company adopts an innovation or an improvement that has worked for another.

1. Global level (between countries). This is a case of unintentional knowledge flows between neighbouring countries as illustrated by the study of the United States spillover to Canadian manufacturing companies (Bernstein, J., 2000), or it can accompany the process of knowledge transfer that happens when countries have international collaboration as in the study of spillover effects from industrial partnership between Sweden and Brazil (Rehme, J., Staffan, S., 2017).

The type of knowledge has an impact on the manner in which spillover flows will extent from one agent to another. It should be noted that tacit knowledge can be exchanged only at the individual level, while explicit knowledge can be exchanged by face-to-face contact at the individual, enterprise or even at the global level (Fallah, M.H., Sherwat, I., 2004).

The majority of academic literature identifies the following types of knowledge spillovers:

1. Based on the level of diffusion:

- knowledge spillovers at the micro-level (individual level and enterprise level);

- knowledge spillovers at the macro-level (global level); 
2. Based on the object of diffusion:

- rent-spillovers are related to the flow of goods between companies (Griliches, 1992; Montoro-Sa'nchez, A. et al., 2011). If goods are used as inputs in the productive process of another company, the latter company will receive some product innovation as a spillover from that input (Verspagen, 1997);

- pure knowledge spillovers refer to the effect of research performed by economic agent i (a company, an industry or a country) to improve technology in a second economic agent $\mathrm{j}$ without $\mathrm{j}$ having to pay for it (Griliches, 1992). Pure knowledge spillovers usually enhance the performance of a company's own R\&D (Verspagen, 1997).

3. Based on the direction of diffusion:

- intra-industry or vertical knowledge spillovers occur if the company that is the knowledge recipient operates in a different field from the sender (Kaiser, 2002); happen as a result of industry specialization (Marshall, 1920; Arrow, 1962; Romer 1986);

- inter-industry or horizontal knowledge spillovers arise when the recipient and sender companies conduct activity in the same field of business (Kaiser, 2002); happen as a result of the diversity of knowledge between complementary industries or customers and suppliers that service each other.

\section{Mechanism of Knowledge Spillovers}

\section{There are a number of ways that knowledge can be "spilled over" to other agents:}

1. Collaborations between companies and universities. Technology development leads to knowledge spillovers by direct project participation from different companies, and indirect involvement in various business and scientific projects, and through publications.

2. Knowledge can be transferred through joint R\&T and R\&D projects in the specific development of the project (classical).

3. The human capital acquisition. Employees leaving the company, along with the skills and knowledge they have acquired working in the company, can either establish their own business or are employed by other companies (Rehme, J., Staffan, S., 2017).

As David B. Audretsch (1998, p. 23) puts it: "The theory of knowledge spillovers, derived from the knowledge production function, suggests that the propensity for innovative activity to cluster spatially will be the greatest in industries where tacit knowledge plays an important role. (...) it is tacit knowledge, as opposed to information, which can only be transmitted informally, and typically demands direct and repeated contacts."

There are three main theories on knowledge spillovers and local competition (Van Stel, A.J., Nieuwenhuijsen, H.R., 2004). These theories explain the exact mechanisms of knowledge spillovers and focus on two questions (Van Stel, A., 2006):

1. Do knowledge spillovers primarily arise within one sector or, alternatively, do spillovers occur between different sectors?

2. What impact does local competition have on innovative activity and economic growth?

The first theory introduced by Marshall, A. (1890) was developed by Arrow, K. (1962), and Romer, P. (1986), and abbreviated as MAR. The key point of MAR theory can be summarized as follows:

- knowledge spillovers are most effective between homogeneous companies and primarily arise within one sector, industry specialization enhances knowledge spillovers and stimulate economic growth, for example, microchip manufacturing industry in Silicon Valley (Glaeser E.L. et al., 1992, p. 1130);

- a local monopoly is beneficial for innovation development and economic growth; regional sectoral growth is maximized if the industry sector is dominant in the region, and if a local competition is not too strong (Van 
Stel, A.J., Nieuwenhuijsen, H.R. 2004);

- knowledge accumulated by one company tends to contribute to the development of technologically close companies (Jaffe, A.B.,1986) and produces an additional incentive for innovation development;

Therefore, according to MAR theory, the geographic concentration of the production allows companies to benefit from the knowledge spillovers within the industry sector, which, in turn, drives economic growth for industries in specialized sectors that are geographically concentrated.

The second theory was developed by Porter, M.E. (1990). This theory agrees with the MAR's statement that knowledge spillovers among companies doing business in industrial sectors, which are concentrated in certain region, enhance economic growth. In contrast to MAR theory, which emphasizes the negative effect of competition on innovation development, Porter's theory states that local competition has a positive effect on economic growth through acceleration of imitation and enhancing innovation activity. If a company does not implement innovations, it will lose its competitive position. Therefore, in competitive environment companies are "forced" to be innovative (Van Stel, A.J., Nieuwenhuijsen, H.R. 2004). Italian ceramics and gold jewellery industries are an example that proves Porter's theory (Glaeser E.L. et al., 1992, p. 1128).

The third theory was developed by Jacobs, J. (1969) and emphasizes the importance of local knowledge spillovers, which work out most effectively between companies conducting different activities. In this case, there are intra-industry or vertical knowledge spillovers. Jacobs' theory (1969) and Porter's theory (1990) have the same statement, that local competition increases the implementation of technological innovation and, consequently, force economic development (Van Stel, A.J., Nieuwenhuijsen, H.R. 2004).

\section{Conclusions}

This paper examines $R \& D$ spillovers and their impact on innovation. R\&D spillovers enhance innovation development via knowledge diffusion between different agents. There are various types of R\&D spillovers: knowledge, market, and network spillovers. The new growth theory primarily focuses on knowledge spillovers. The term "knowledge spillovers" means unintentional transmission of information and knowledge through various channels of knowledge exchange from one economic unit to another without full compensation for the economic unit, which had created such knowledge. Information can be transferred across borders at practically zero cost, and knowledge spillovers occur due to imperfect appropriability of knowledge implemented in innovation.

There is a connection between knowledge transfers, knowledge spillovers and knowledge externalities. The key difference between knowledge transfer and knowledge spillovers is knowledge holders' intention. Knowledge externalities result from the effects of the knowledge transfers and knowledge spillovers. In most cases, knowledge externalities are positive.

The object of knowledge spillovers is information and knowledge. Tacit knowledge "spills over" at the individual level, while explicit knowledge can be exchanged at the individual, enterprise and global levels. Therefore, subjects of knowledge spillovers include people, companies (enterprises, firms), organizations, industrial sectors, and countries.

Analysis of academic literature allowed arranging the types of knowledge spillovers into groups based on three criteria: level of diffusion, object of diffusion, and direction of diffusion. Theories of knowledge spillovers explain how knowledge spillovers impact innovation development and promote economic growth depending on geographic concentration of the production and local competition. 


\section{References}

Agarwal, R., Audretsch, D., Sarkar, M. (2010). Knowledge spillovers and strategic entrepreneurship. Strategic entrepreneurship journal, 4: 271-283.

Arrow, K., (1962). Economic welfare and the allocation of resources for invention. http://www.nber.org/chapters/c2144

Audretsch, D.B. (1998). Agglomeration and the location of innovative activity. Oxford Review Of Economic Policy, 14(2): 18-29. https://doi.org/10.1093/oxrep/14.2.18

Audretsch, D.B. (1999). Knowledge spillovers and the role of small firms, paper presented at the Crenos conference on technological externalities and spatial location, University of Cagliari, 24th-25th September.

Bakhtiari, S., Robert, B. (2017). The role of spillovers in research and development expenditure in Australian industries. https://www. industry.gov.au/sites/g/files/net3906/f/May\%202018/document/pdf/the_role_of_spillovers_in_research_and_development_expenditure_in_australian_industries.pdf

Batkovskiy, A.M.; Leonov, A.V.; Pronin, A.Yu.; Semenova, E.G.; Fomina, A.V.; Balashov, V.M. (2019). Sustainable development of Industry 4.0: the case of high-tech products system design. Entrepreneurship and Sustainability Issues, 6(4), 1823-1838. http://doi. org/10.9770/jesi.2019.6.4(20)

Bayar, A., Dramais F., Hubic A., Malek-Mansour J., Mohora C., Opese M., Pollitt H. (2007). An analysis of R\&D spillover, productivity, and growth effects in the EU. Knowledge for growth: role and dynamics of corporate R\&D. First European conference Seville / Spain, 8th-9th of October 2007.

Bernstein, J. (2000). Canadian manufacturing, U.S. R\&D spillovers and communication infrastructure. The Review of Economics And Statistics, 82 (4): 608-615.

Bezpalov, V.V., Fedyunin, D.V., Solopova, N.A., Avtonomova, S.A., Lochan, S.A. (2019). A model for managing the innovation-driven development of a regional industrial complex. Entrepreneurship and Sustainability Issues, 6(4), 1884-1896. http://doi.org/10.9770/ jesi.2019.6.4(24)

Branstetter, L., Saggi, K. (2011) Intellectual property rights, foreign direct investment, and industrial development. Economic journal, 121(555): 1161-1191.

Breschi, S., Lissoni, F. (2000). Knowledge spillovers and local innovation systems: a critical survey. URL: https://www.econstor.eu/ handle/10419/114910

Cohen, W., Levinthal, D. (1989). Innovating and learning: the two faces of R\&D. Economic Journal, 99(397): 569-596.

De Bondt, R. (1996). Spillovers and innovative activities. International Journal of Industrial Organization, 15: 1-28.

Estimating innovation spillovers: an international sectoral and UK enterprise study. URL: https://assets.publishing.service.gov.uk/government/uploads/system/uploads/attachment_data/file/384344/bis-14-1269-estimating-innovation-spillovers-an-international-sectoraland-uk-enterprise-study.pdf

Fallah, M.H., Sherwat, I. (2004). Knowledge spillover and innovation in technological clusters. URL: https://www.researchgate.net/ publication/228796741_Knowledge_spillover_and_innovation_in_technological_clusters

Feriyanto, N., Muafi, Dityawarman, E. A. (2019). Regional spillover effect to Gross Regional Development Product (GRDP) in The Special Region of Yogyakarta, Indonesia. Entrepreneurship and Sustainability Issues, 6(3), 1118-1134. http://doi.org/10.9770/ jesi.2019.6.3(19)

Ferreira, J.J., Ratten, V., Dana, L.-P. (2017). Knowledge spillover-based strategic entrepreneurship. International Entrepreneurship And Management Journal, 13: 161-167. https://doi.org/10.1007/s11365-016-0415-6

Girdzijauskaite, E.; Radzeviciene, A.; Jakubavicius, A. (2019). Impact of international branch campus KPIs on the university competitiveness: FARE method. Insights into Regional Development, 1(2), 171-180. https://doi.org/10.9770/ird.2019.1.2(7)

Glaeser, E.L., Kallal H.D., Scheinkman, J.A., Shleifer, A. (1992). Growth in Cities. Journal of political economy, 100(1): $126-52$.

Griliches, Z. (1979). Issues in assessing the contribution of research and development to productivity growth. The bell journal of economics, 10(1): 92-116. https://doi.org/10.2307/3003321

Griliches, Z. (1992). The search for R\&D spillovers. Scandinavian Journal of Economics, 94: 29-48. 
Grossman, G., Helpman, E. (1990). Trade, Innovation, and Growth. American Economic Review, 80(2): 86-91.

Grossman, G., Helpman, E. (1991). Innovation and growth in the global economy. MIT Press, Cambridge.

Grossman, G., Helpman, E. (2015). Globalization and Growth. American economic review: papers \& proceedings, $105(5): 100-104$. http://dx.doi.org/10.1257/aer.p20151068

Hasan, M., Hatidja, St., Nurjanna, Guampe, F.A.; Gempita, Ma'ruf, M.I. (2019). Entrepreneurship learning, positive psychological capital and entrepreneur competence of students: a research study, Entrepreneurship and Sustainability Issues, 7(1), 425-437. http://doi. org/10.9770/jesi.2019.7.1(30)

Hrivnak, M., Melichova, K., Fazikova, M., Rohacikova, O. (2019). University graduates, knowledge spill-overs and localization of knowledge intensive ventures - case of post-socialistic country. Entrepreneurship and Sustainability Issues, 7(1), 146-165. http://doi. org/10.9770/jesi.2019.7.1(12)

Jacobs, J. (1969). The economy of cities. Vintage, New York.

Jaffe, A.B. (1986). Technological opportunity and spillovers of R\&D: evidence from firms' patents, profits and market value, NBER Working Papers, 1815. URL: http://www.nber.org/papers/w1815.pdf

Jaffe, A.B. (1998). The importance of "spillovers" in the policy mission of the advanced technology program. Journal of Technology Transfer, 23(2): 11-19.

Jones, C.I., and John, C.W. (1998). Measuring the social return to R\&D. Quarterly Journal of Economics, 113(4): 1119-1135.

Kafouros, M.I., Buckley, P.J. (2008). Under what conditions do firms benefit from the research efforts of other organizations? Research Policy, 37: 225-39.

Kaiser, U. (2002). Measuring knowledge spillovers in manufacturing and services: an empirical assessment of alternative approaches. Research Policy, 31: 125-44.

Keller, W. (1998). Are international R\&D spillovers trade-related? Analyzing spillovers among randomly matched trade partners. European Economic Review, 42(8): 1469-1481.

Keller, W. (2004). International technology diffusion. Journal of economic literature, 42(3): 742-782.

Kenta, I., Rene, B., Fukao, K., Young, G., Kwon, H.U. (2015). Buyers, suppliers, and R\&D spillovers. RIETI discussion paper, (15-E-047).

Ko, W.W., Liu, G. (2015). Understanding the process of knowledge spillovers: the learning to become social enterprises. Strategic entrepreneurship journal, 9: 263-285. https://doi.org/10.1002/sej.1198

Krchová, H. (2019). Project tools in relation to the implementation of the ability of innovation companies in Slovakia. Entrepreneurship and Sustainability Issues, 7(1), 291-302. http://doi.org/10.9770/jesi.2019.7.1(22)

Lee, K., Chen, K., Yoon, M. (2016). Comparing the productivity impacts of knowledge spillovers from network and arm's length industries: findings from business groups in Korea. Industrial and Corporate Change, 28(3): 407-427. https://doi.org/10.1093/icc/dtv036

Levin, R.C., Reiss, P.C. (1988). Cost-reducing and demand-creating R\&D with spillovers. Rand journal of economics, 19 (4): $538-56$. Lucas, R.E. (1988). On the mechanics of economic development. Journal of monetary economics, 22: 3-42.

Lysytsia, N., Martynenko, M., Bielikova, N., Gron, O., Us, M. (2019). Directions of social partnership of employers and universities in the sphere of economic education in Ukraine. Entrepreneurship and Sustainability Issues, 7(1), 336-352. http://doi.org/10.9770/ jesi.2019.7.1(25)

Marshall, A. (1920). Principles of Economics. $8^{\text {th }}$ Edition. Macmillan, London.

Medhurst, J., Marsden, J., Jugnauth, F., Peacock, M., Lonsdale, J. (2014). An economic analysis of spillovers from programmes of technological innovation support. URL: https://assets.publishing.service.gov.uk/government/uploads/system/uploads/attachment_data/ file/288110/bis-14-653-economic analysis-of-spillovers-from-programmes-of-technological-innovation-support.pdf

Miroshnychenko, O. (2019). Place of knowledge spillovers in innovation diffusion. Economics. Finance. Business. Management, Proceedings of the $1^{\text {st }}$ International Economic Forum, 1(2): 30-31.

Montoro-Sa'nchez, A., Ortiz-de-Urbina-Criado, M., Mora-Valentı'n, E. (2011). Effects of knowledge spillovers on innovation and col- 
laboration in science and technology parks. Journal of Knowledge Management, 15(6): 948-970.

Petrenko, Y., Vechkinzova, E., Antonov, V. (2019). Transition from the industrial clusters to the smart specialization of the regions in Kazakhstan. Insights into Regional Development, 1(2), 118-128. https://doi.org/10.9770/ird.2019.1.2(3)

Pigou, A.C. (1920). The economics of welfare. http://oll.libertyfund.org/EBooks/Pigou_0316.pdf

Porter, M.E. (1990). The competitive advantage of nations. Free Press, NewYork.

Ramadani, V., Abazi-Alili, H., Dana, L.P., Rexhepi, G., Ibraimi, S. (2017). The impact of knowledge spillovers and innovation on firmperformance: findings from the Balkans countries. International Entrepreneurship and Management Journal, 13: 299-325. https://doi. org/10.1007/s11365-016-0393-8

Rehme, J., Staffan, S. (2017). Spillover effects. The Gripen project with a focus on the industrial partnership between Sweden and Brazil. https://www.tillvaxtanalys.se/download/18.6868ecb315d1f19d113cdc84/1504007320196/Bakgrundsrapport\%20Link\%C3\%B6 pings $\% 20$ Universitet.pdf

Romer, P.M. (1986). Increasing returns and long-run growth. Journal of Political Economy, 94: 1002-1037.

Romer, P.M. (1994). The origins of endogenous growth. Journal of Economic Perspectives, 8(1): 3-22.

Simonen, J., McCann, P. (2008). Innovation, R\&D cooperation and labor recruitment: evidence from Finland. Small Business Economics, 31: 181-94.

Šimonová, J; Čentéš, J.; Beleš, A. 2019. Financial analysis of innovative forms of money, Entrepreneurship and Sustainability Issues 7(1): 69-80. http://doi.org/10.9770/jesi.2019.7.1(6)

Van Stel, A. (2006). Empirical analysis of entrepreneurship and economic growth. https://doi.org/10.1007/0-387-29419-8

Van Stel, A.J., Nieuwenhuijsen, H.R. (2004). Knowledge spillovers and economic growth: an analysis using data of Dutch regions in the period 1987-1995. Regional studies, 38 (4): 393-407.

Verspagen, B. (1997). Measuring intersectoral technology spillovers: estimates from the European and US patent office databases", Economic systems research, 9: 47-65.

Verspagen, B., De Loo, I. (1999). Technology spillovers between sectors and over time. Technological Forecasting and Social Change, 60: 215-35.

Yang, H., Steensma, H.K. (2014). When do firms rely on their knowledge spillover recipients for guidance in exploring unfamiliar knowledge? Research policy, 43(9): 1496-1507. https://doi.org/10.1016/j.respol.2014.04.016

Zenona Ona ATKOČIŪnIENĖ, PhD, Professor, Head of the Department of Information and knowledge management, Faculty of communication, Vilnius University, Lithuania

ORCID ID: https://orcid.org/0000-0002-7987-7002

Olga MIROSHNYCHENKO, PhD in Economics, Assoc. Prof. of the Enterprise Economics Department, Taras Shevchenko National University of Kyiv, Ukraine

ORCID ID: https://orcid.org/0000-0003-3822-4803 